\title{
Nano-Fe as feed additive improves the hematological and immunological parameters of fish, Labeo rohita $\mathrm{H}$.
}

\author{
T. Behera $\cdot$ P. Swain • P. V. Rangacharulu • \\ M. Samanta
}

Received: 4 April 2013/Accepted: 1 June 2013/Published online: 27 June 2013

(C) The Author(s) 2013. This article is published with open access at Springerlink.com

\begin{abstract}
An experiment was conducted to compare the effects of iron oxide nanoparticles $\left(T_{1}\right)$ and ferrous sulfate $\left(T_{2}\right)$ on Indian major carp, Labeo rohita $\mathrm{H}$. There were significant differences $(P<0.05)$ in the final weight of $T_{1}$ and $T_{2}$ compared with the control. Survival rates were not affected by the dietary treatments. Fish fed a basal diet (control) showed lower $(P<0.05)$ iron content in muscle compared to $T_{1}$ and $T_{2}$. Furthermore, the highest value $(P<0.05)$ of iron content was observed in $T_{1}$. In addition, RBCs and hemoglobin levels were significantly higher in $T_{1}$ as compared to other treated groups. Different innate immune parameters such as respiratory burst activity, bactericidal activity and myeloperoxidase activity were higher in nano-Fe-treated diet $\left(T_{1}\right)$ as compared to other iron source $\left(T_{2}\right)$ and control in 30 days post-feeding. Moreover, nano-Fe appeared to be more effective $(P<0.05)$ than ferrous sulfate in increasing muscle iron and hemoglobin contents. Dietary administration of nanoFe did not cause any oxidative damage, but improved antioxidant enzymatic activities (SOD and GSH level) irrespective of different iron sources in the basal diet.
\end{abstract}

Keywords Fish · Feed · Iron · Nano-Fe . Immune response $\cdot$ Labeo rohita

T. Behera $\cdot$ P. Swain $(\bowtie) \cdot$ M. Samanta

Fish Health Management Division, Central Institute

of Freshwater Aquaculture, Kausalyaganga,

Bhubaneswar 751002 , Orissa, India

e-mail: truptibiotech2007@gmail.com

P. V. Rangacharulu

Fish Nutrition and Physiology Division, R.R.C. Central Institute of Freshwater Aquaculture, Vijayawada, Andhra Pradesh, India

\section{Introduction}

Iron $(\mathrm{Fe})$ is an indispensable element for the functioning of organs and tissues of higher animals, including fish, because of its vital role in physiological processes such as oxygen transport, cellular respiration and lipid oxidation reactions (Lee et al. 1981; Andersen et al. 1997). Iron is also one of the most essential micronutrients in terms of its effect on the functioning of the immune system and defense against various infections (Beisel 1982; Bhaskaram 1988). Iron deficiency causes immune suppression, growth depression, changes in hematological parameters, susceptibility to diseases, poor food conversion and microcytic anemia in common carp (Tacon 1992; Andersen et al. 1996; Kawatsu 1972; Sakamoto and Yone 1978). Iron is thus essential and in excess can be toxic (Salte et al. 1994; Andersen et al. 1997). Fish can absorb soluble iron from the water across the gill membrane and intestinal mucosa (Roedar and Roedar 1966; Sealey et al. 1997). However, feed is considered to be a major source of iron for fish, due to low concentration of soluble iron in natural water and limited iron passage across the gills (NRC 1993; Bury et al. 2003). As in higher vertebrates, the mechanisms involved in the absorption and regulation of iron in fish are poorly understood (Lall 2002). Till now several reports showed contradictory results for the dietary iron requirements in fish, which vary from species to species and in different environmental conditions (Hem 1989). The minimum dietary iron requirement in Indian major carp, rohu, Labeo rohita $\mathrm{H}$. was $0.014 \%$ of dry diet (Jhingran and Pullin 1985).

Different chemical forms of iron exhibit different bioavailabilities in animals (Forbes et al. 1989); however, this information is lacking in fish (Lall 2002). Most of the chemical forms of iron have poor bioavailability to fish. 
However, ferrous fumarate $\left(\mathrm{C}_{4} \mathrm{H}_{2} \mathrm{FeO}_{4}\right)$, ferrous sulfate $\left(\mathrm{FeSO}_{4} \bullet 7 \mathrm{H}_{2} \mathrm{O}\right)$ and heme iron are highly bioavailable than other water-insoluble elemental and non-heme form of iron (Melodie 2011; Coffman 2011), whereas ferric phosphate nanoparticles $\left(\mathrm{FePO}_{4}\right)$ have low nutritional value due to their low bioavailability (Rohner et al. 2007). At present, not a single evidence showed iron sulfide is bioavailable to fish. Using a bioavailable form, dietary iron will improve the quality of fish feed for the aquaculture industry. Different forms of iron cause unacceptable changes in the color or taste of foods, are poorly water-soluble, cause sensory changes and are not well absorbed. Iron oxides, on the other hand, have better sensory performance than phosphates, but are poorly soluble and may have lower bioavailability (Hilty et al. 2011). Recently, a preliminary report showed that nanostructured iron oxide $\left(\mathrm{Fe}_{2} \mathrm{O}_{3}\right)$ could be as bioavailable as ferrous sulfates $\left(\mathrm{FeSO}_{4}\right)$ in rats (Hilty et al. 2011). Different chemical forms of iron have different degrees of limitations to fulfilling the dietary iron requirements in fish. Determining the optimum iron feed concentration and its suitable bioavailable form is therefore a necessary task for the performance of any farmed fish of interest. However, such data are limited particularly in teleost fish.

Nanotechnology holds promise for both medication and nutrition, because materials at the nanometer dimension exhibit novel properties different from those of isolated atom and bulk material (Albrecht et al. 2006; Wang et al. 2007). Iron oxide nanoparticles are of great interest due to their unique physicochemical properties and have a great potential in human biomedical applications, food additives, antimicrobial additives, drug carriers, etc. (Huber 2005). Moreover, food additives in the nano forms are being increasingly used including iron-fortified cereals and drinks for human consumption (Hilty et al. 2010a, b). Recently, preliminary reports showed that iron oxide nanoparticles could boost bioavailability than other forms of iron nanoparticles in both humans and rats through dietary administration (Stephen 2007). Iron is also associated with protein in animal tissues (Barton and Edwards 2000). Consequently, muscle protein and seafood are dependable dietary sources of the minerals (Gibson 1990). Deteriorative oxidative reactions in meat lead to losses of both nutritional value and food quality. To increase the oxidative stability and meat quality, antioxidants such as iron have been added to the feed of farm animals (Min et al. 2008).

However, not a single study has been done to incorporate nano-Fe into fish feed based on growth performance, hematology, immune response, tissue deposition and antioxidant enzymatic activities. Very little information is available regarding the mineral requirements of Indian major carps, Labeo rohita, but the same assumes great importance in feed formulations. Under practical farming conditions, iron deficiencies occur mainly due to low bioavailable iron in commercial fish feeds. Therefore, in this study we evaluated the application of different iron sources, including iron nanoparticles (nano-Fe) and ferrous sulfate $\left(\mathrm{FeSO}_{4} \bullet 7 \mathrm{H}_{2} \mathrm{O}\right)$, as feed additives in diets for, rohu, Labeo rohita $\mathrm{H}$. which is one of the commercially important and valuable freshwater fish species cultured in India.

\section{Materials and methods}

Materials and diet

Iron oxide $\left(\mathrm{Fe}_{2} \mathrm{O}_{3}\right)$ nanoparticles (nano-Fe) (average size $<50 \mathrm{~nm}$ by TEM analysis, purity $\geq 98 \%$ trace metals basis) and ferrous sulfate $\left(\mathrm{FeSO}_{4} \bullet 7 \mathrm{H}_{2} \mathrm{O}\right)$ were purchased from Sigma-Aldrich, USA. The nano-Fe was in the redox state of zero. The desired amount of nano-Fe was diluted (evenly dispersed) with dechlorinated water to make up a suitable dose for oral administration through the feed. Commercial kits of superoxide dismutase (SOD) and glutathione assay (GSH) were purchased from Sigma-Aldrich, USA, and Quanti-Chrome assay Kits, respectively. Ingredients and chemical composition of the basal diets used in the study were according to Lovell (1998). Basal diet formulations are shown in Table 1 . The analysis of the iron concentrations in the experimental diets shows the approximate values of the expected concentration as given in Table 1.

Table 1 Formulations of experimental diets

\begin{tabular}{lr}
\hline Ingredients & $(\%)$ \\
\hline Casein & 32 \\
Gelatin & 8 \\
Dextrine & 28 \\
Cellulose & 19 \\
Fat $^{\mathrm{a}}$ & 6 \\
Carboxy methyl cellulose $^{\text {Mineral premix }}{ }^{\mathrm{b}}$ & 2 \\
Vitamin premix $^{\mathrm{c}}$ & 4 \\
\end{tabular}

\footnotetext{
a The mixture of fish oil and lard (1:1)

b Mineral premix (\%): $\mathrm{KAl}\left(\mathrm{SO}_{4}\right)_{2}, \quad 0.159 ; \mathrm{CaCO}_{3}, \quad 18.101$; $\mathrm{Ca}\left(\mathrm{H}_{2} \mathrm{PO}_{4}\right)_{2}, 44.601 ; \mathrm{MgSO}_{4}, 5.216 ; \mathrm{CoCl}_{2}, 0.07 ; \mathrm{KCl}, 16.553 ; \mathrm{Na}_{2}$ $\mathrm{SeO}_{3}, 1.338 ; \mathrm{MnSO}_{4} \cdot \mathrm{H}_{2} \mathrm{O}, 0.07 ; \mathrm{KI}, 0.014 ; \mathrm{ZnSO}_{4}, 0.192 ; \mathrm{NaH}_{2} \mathrm{PO}_{4}$, 13.605; and $\mathrm{CuSO}_{4} \cdot 5 \mathrm{H}_{2} \mathrm{O}, 0.075$

c Vitamin premix: thiamin hydrochloride, $10 \mathrm{mg} \mathrm{kg}^{-1}$; riboflavin, $20 \mathrm{mg} \mathrm{kg}^{-1}$; calcium pantothenate, $40 \mathrm{mg} \mathrm{kg}^{-1}$; nicotinic acid, $50 \mathrm{mg} \mathrm{kg}^{-1}$; pyridoxine hydrochloride, $10 \mathrm{mg} \mathrm{kg}^{-1}$; folic acid, $5 \mathrm{mg} \mathrm{kg}^{-1}$; inositol, $400 \mathrm{mg} \mathrm{kg}^{-1}$; choline chloride, 2,000 $\mathrm{mg} \mathrm{kg}^{-1}$; menadione, $10 \mathrm{mg} \mathrm{kg}^{-1}$; cholecalciferol, 1,500 IU; biotin, $1 \mathrm{mg} \mathrm{kg}{ }^{-1}$; vitamin $\mathrm{B}_{12}, 0.02 \mathrm{mg} \mathrm{kg}^{-1}$; vitamin A, 3,000 IU; vitamin E, $50 \mathrm{IU}$; and vitamin C, $200 \mathrm{mg} \mathrm{kg}^{-1}$
} 


\section{Diet formulations}

Six tanks with duplicates for treatments and control were used. Three treatments were used. In treatment $1\left(T_{1}\right)$ and treatment $2\left(T_{2}\right)$, nano-Fe and ferrous sulfate (best bioavailable and soluble iron supplement) were added to the experimental basal diets at the rate of $0.5 \mathrm{mg} \mathrm{kg}^{-1}$ dry feed weight, respectively. The control groups included only basal diet without iron supplements. The ingredients and different iron sources were mixed, extruded and air dried at room temperature. Then these diets were kept at $-20{ }^{\circ} \mathrm{C}$ until use. To mix adequately, nano-Fe or ferrous sulfate $\left(\mathrm{FeSO}_{4} \bullet 7 \mathrm{H}_{2} \mathrm{O}\right)$ was slowly applied to the diet ingredients, mixing part by part in a mixer. The final actual concentration of iron in each diet was determined and is shown in Table 2.

Fish and experimental design

Indian major carp, Labeo rohita (rohu), juveniles having similar average weight (Table 3 ) were acclimatized in the wet laboratory of Fish Health Management Division of Central Institute of Freshwater Aquaculture (CIFA), Kausalyaganga, India, 30 days prior to the start of the experiment. Water temperature of the experimental tanks was $27-30{ }^{\circ} \mathrm{C}$ with a photoperiod of 12 -h light and 12-h darkness. The tanks were supplied with running freshwater. For water quality control, temperature and dissolved oxygen (DO) were measured daily, and weekly analyses were conducted for total ammonium, nitrite and $\mathrm{pH}$ levels using the kit.

Table 2 The actual concentration of iron in all experimental diets

\begin{tabular}{llll}
\hline Group & Control & $T_{1}$ & $T_{2}$ \\
\hline Iron sources & - & Nano-Fe & $\begin{array}{c}\text { Ferrous } \\
\text { sulfate }\end{array}$ \\
$\begin{array}{c}\text { Actual concentration } \\
\left(\mathrm{mg} \mathrm{kg}^{-1}\right)\end{array}$ & $0.05 \pm 0.0005$ & $0.54 \pm 0.002$ & $0.55 \pm 0.0009$ \\
\hline
\end{tabular}

Table 3 Growth performance and survivability of Labeo rohita $\mathrm{H}$. supplemented with different iron sources (nano-Fe and ferrous sulfate, $T_{1}$ and $T_{2}$, respectively) and without iron (control)

\begin{tabular}{llll}
\hline Group/treatment & $T_{1}$ & $T_{2}$ & Control \\
\hline Initial weight $(\mathrm{g})$ & $20.22 \pm 0.44^{\mathrm{a}}$ & $20.29 \pm 0.68^{\mathrm{a}}$ & $20.45 \pm 0.50^{\mathrm{a}}$ \\
Final weight $(\mathrm{g})$ & $38.07 \pm 0.9^{\mathrm{a}}$ & $36.0 \pm 0.0^{\mathrm{a}}$ & $28.25 \pm 0.88^{\mathrm{b}}$ \\
Survival rate $(\%)$ & $100^{\mathrm{a}}$ & $100^{\mathrm{a}}$ & $100^{\mathrm{a}}$ \\
\hline
\end{tabular}

Results are presented as mean \pm SE of triplicate observations. Means bearing different superscripts were significantly different $(P<0.05)$
Then the fish were distributed into six tanks at 20 fish per tank with similar initial weights. The experiment was conducted as a completely randomized design with three treatments ( $T_{1}, T_{2}$ and Control). Daily (twice a day) feeding rate was about $3 \%$ of total body weight and care was also taken to ensure that all the feed added to the tanks was eaten. Every day, the diet remaining in each tank was collected by siphoning before the second day's feeding. A daily record was kept of feed offered and the remains. Every day, each tank was cleaned with $50 \%$ water being changed.

Feed and tissue analysis

Feed and tissue (gill, muscle and liver) samples were dried. One gram of dried tissue samples was digested separately with $10 \mathrm{ml}$ of $\mathrm{HNO}_{3}$ in a microwave device (CEM MDS 2100). Following digestion, the sample was diluted with distilled water to $20 \mathrm{ml}$ and filtered. A Varian AA 20 Plus flame atomic absorption spectrophotometer was used for the determination of the metal concentrations.

\section{Hematological parameters}

Different hematological parameters were studied 30 days post-feeding (dpi) in all the treated groups. Red blood cells (RBCs) and white blood cells (WBCs) diluting fluids were used for determining total erythrocyte and leucocyte counts. It was done by mixing $20 \mu \mathrm{l}$ of blood with $3,980 \mu \mathrm{l}$ of the corresponding diluting fluid in a clean test tube. Cell counts were performed using a Neubauer's counting chamber. The hemoglobin level of blood was analyzed following the cyanomethemoglobin method using Drabkins Fluid (Qualigens Chemicals) (Darbkin 1950). The absorbance was measured using a spectrophotometer at $540 \mathrm{~nm}$ and the final concentration was calculated by comparing with the standard cyanmethemoglobin (Qualigens Chemicals). The hemoglobin concentration was then calculated using the following formula: hemoglobin $(\mathrm{g} / \mathrm{dl})=[\mathrm{OD}(\mathrm{T}) / \mathrm{OD}(\mathrm{S})] \times[251 /$ $1,000] \times 60$ where $\mathrm{OD}(\mathrm{T})$ is the absorbance of the test and OD $(\mathrm{S})$ the absorbance of the standard. Serum protein was estimated with a BCA protein estimation kit (total protein) (Bangalore Genei) and albumin by albumin estimation kit (Qualigens Diagnostics, Glaxo smithkline). Albumin was estimated by the bromocresol green binding method (Doumass et al. 1971). The absorbance of the standard and test was measured against a blank in a spectrophotometer at $630 \mathrm{~nm}$. Globulin was calculated by subtracting albumin values from total serum protein. A/G ratio was calculated by dividing albumin values by globulin values. 
Innate immune parameters

Different innate immune parameters were studied in all the experimental groups at $30 \mathrm{dpi}$.

\section{Respiratory burst activity}

The respiratory burst activity of the phagocytes was performed using nitroblue tetrazolium (NBT) assay following the method of (Anderson and Siwicki 1994). Blood (50 $\mu \mathrm{l})$ was placed into the wells of U-bottom microtiter plates and incubated at $37{ }^{\circ} \mathrm{C}$ for $1 \mathrm{~h}$ to allow adhesion of cells. Then the supernatant was removed and the wells were washed three times in PBS. After washing, $50 \mu \mathrm{l}$ of $0.2 \%$ NBT was added and incubated for a further $1 \mathrm{~h}$. The cells were then fixed with $100 \%$ methanol for 2-3 min and washed three times with $30 \%$ methanol. The plates were air dried, and $60 \mu 12$ N potassium hydroxide and $70 \mu$ dimethyl sulfoxide were added to each well. The OD (optical density) was recorded in an ELISA reader (BIORAD-USA) at $540 \mathrm{~nm}$.

\section{Serum bactericidal activity}

The serum was assayed for bactericidal activity as described by Rainger and Rowley (1993). For this, Aeromonas hydrophila culture was centrifuged and the pellet washed and suspended in PBS. The optical density (OD) of the suspension was adjusted to 0.65 at $540 \mathrm{~nm}$. This bacterial suspension was serially diluted (1:10) with PBS. Serum bactericidal activity was determined by incubating $2 \mu \mathrm{l}$ of the diluted A. hydrophila cell suspension with $20 \mu \mathrm{l}$ of serum in a micro-vial for $1 \mathrm{~h}$ at $37^{\circ} \mathrm{C}$. In the control group, PBS was used in the place of serum. After incubation, the number of viable bacteria was determined by counting the colonies grown on nutrient agar plate for $24 \mathrm{~h}$ at $37^{\circ} \mathrm{C}$.

\section{Alternative complement activity $\left(\mathrm{ACH}_{50}\right)$}

The determination of alternative serum complement activity was done according to the previous method with little modifications (Sitja-Bobadilla et al. 2003). Rabbit red blood cells (RRBCs, $2.5 \times 10^{8}$ cells $\mathrm{ml}^{-1}$ ) were taken from blood. One hundred microliters of diluted serum (1:25 in HBSS solution containing $10 \mathrm{mM} \mathrm{Mg}^{2+}$ and $10 \mathrm{mM}$ ethylene glycol bis tetraacetate, $\mathrm{pH}$ 7.6) was taken in Eppendorf tubes and mixed with $25 \mu \mathrm{l}$ of RRBCs. The tubes were incubated for $90 \mathrm{~min}$ at $150 \mathrm{rpm}$ at $20{ }^{\circ} \mathrm{C}$ and then centrifuged to spin down the remaining RRBCs. The supernatants were transferred into 96-well plates and measured at $415 \mathrm{~nm}$. The serum dilution factor was plotted in logarithmic scale against the percentage of RRBCs lysed at each dilution. The dilution corresponding to $50 \%$ hemolysis $\mathrm{ml}^{-1}$ was expressed as $\mathrm{ACH}_{50}$.
Oxidative stress and enzymatic activities

Liver tissues were collected in each group separately at 30 days post-feeding, homogenized with ice-cold $0.86 \%$ $\mathrm{NaCl}$ and centrifuged at $12,000 \times g$ at $4{ }^{\circ} \mathrm{C}$. The resulting supernatants were used for the determination of lipid peroxidation by MDA assay, total glutathione (GSH) and superoxide dismutase (SOD) activities using commercial kits (SOD assay kit, Sigma; QuantiChrom ${ }^{\text {TM }}$ Glutathione (GSH) Assay Kit) and malondialdehyde (MDA) assay using the thio-barbituric acid technique (Ohkawa et al. 1979). The activities of SOD, GSH and MDA were measured as per the calculation given in the kit and the protocol.

\section{Results}

Water quality and growth performance

There was no adverse effect of different iron sources on water quality. Total ammonium $\left(0-0.2 \mathrm{mg} \mathrm{l}^{-1}\right)$, nitrite (0-0.1 $\left.\mathrm{mg} \mathrm{l}^{-1}\right)$ and $\mathrm{pH}(7.4-7.8)$ were stable and within acceptable ranges (Boyd and Tucker 1998). At the beginning, no significant difference was observed in the initial weight between $T_{1}, T_{2}$ and the control (Table 3 ). At the end of experiment (after 30 days of culture), there were significant differences $(P<0.05)$ in relative weight gain and final weight of $T_{1}$ and $T_{2}$, as compared to the control. However, no significant differences $(P<0.05)$ in relative weight gain and final weight between $T_{1}$ and $T_{2}$ was found (Table 3). Survival rates were not affected by the administrations of dietary iron in the whole experimental period.

Iron concentration in serum and muscle tissues

After 30 days of culture, fish fed a nano-Fe diet $\left(T_{1}\right)$ showed a higher $(P<0.05)$ iron content in the muscle tissue as compared to $T_{2}$ and control (Table 4). However, $T_{2}$ showed higher iron content $(P<0.05)$ than the control in muscle tissues. Serum iron content was also significantly higher $(P<0.05)$ in both $T_{1}$ and $T_{2}$ groups as compared to control. However, there was no significant difference $(P>0.05)$ between the groups $T_{1}$ and $T_{2}$ (Table 4 ).

Table 4 Iron contents in serum and muscles

\begin{tabular}{lclc}
\hline & Control & $T_{1}$ & \multicolumn{1}{l}{$T_{2}$} \\
\hline Serum iron $\left(\mathrm{mg}^{-1}\right)$ & $0.98 \pm 0.3^{\mathrm{a}}$ & $3.0 \pm 0.5^{\mathrm{b}}$ & $3.01 \pm 0.2^{\mathrm{b}}$ \\
Muscle $\left(\mu \mathrm{g} \mathrm{g}^{-1}\right)$ & $3.4 \pm 0.75^{\mathrm{a}}$ & $5.8 \pm 0.8^{\mathrm{b}}$ & $5.0 \pm 0.16^{\mathrm{c}}$ \\
\hline
\end{tabular}

Results are presented as mean \pm SE of triplicate observations. Means bearing different superscripts were significantly different $(P<0.05)$ 
Table 5 Hematological parameters and total serum proteins of Labeo rohita $\mathrm{H}$. supplemented with iron oxide nanoparticles (nano-Fe, $T_{1}$ ), ferrous sulfate $\left(T_{2}\right)$ and without any iron (control) in the basal diet

\begin{tabular}{lllllll}
\hline & RBC $\left(10^{6}\right.$ cells $\left.\mu \mathrm{l}\right)$ & WBC $\left(10^{3}\right.$ cells $\left./ \mu \mathrm{l}\right)$ & Hemoglobin $(\mathrm{g} / \mathrm{dl})$ & Total protein $(\mathrm{g} \%)$ & Albumin $(\mathrm{g} \%)$ & Globulin $(\mathrm{g} \%)$ \\
\hline Control & $1.60 \pm 0.15^{\mathrm{a}}$ & $102.38 \pm 0.72^{\mathrm{a}}$ & $7.13 \pm 0.10^{\mathrm{a}}$ & $3.61 \pm 0.02^{\mathrm{a}}$ & $1.23 \pm 0.01^{\mathrm{a}}$ & $2.38 \pm 0.02^{\mathrm{a}}$ \\
$T_{1}$ & $2.92 \pm 0.02^{\mathrm{b}}$ & $102.50 \pm 0.16^{\mathrm{a}}$ & $11.53 \pm 0.11^{\mathrm{b}}$ & $4.70 \pm 0.00^{\mathrm{b}}$ & $1.12 \pm 0^{\mathrm{b}}$ & $3.59 \pm 0^{\mathrm{b}}$ \\
$T_{2}$ & $2.61 \pm 0.02^{\mathrm{c}}$ & $100.45 \pm 1.55^{\mathrm{a}}$ & $10.40 \pm 0.16^{\mathrm{c}}$ & $4.63 \pm 0.01^{\mathrm{b}}$ & $1.15 \pm 0^{\mathrm{b}}$ & $3.49 \pm 0.02^{\mathrm{b}}$ \\
\hline
\end{tabular}

Means bearing different superscripts were significantly different $(P<0.05)$

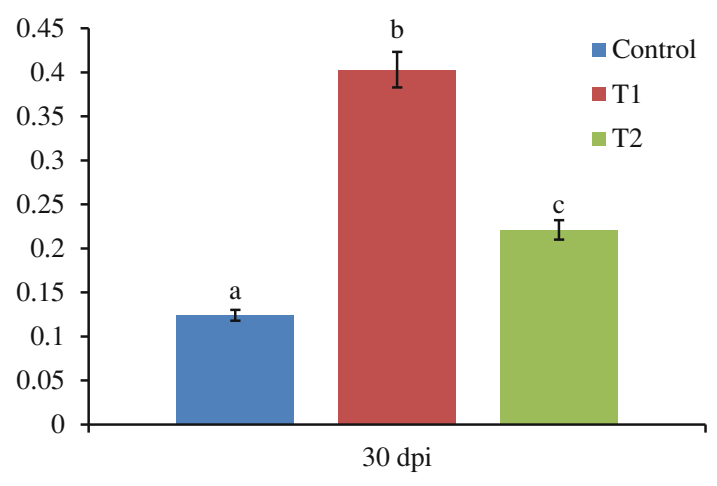

Fig. 1 Effect of dietary nano-Fe on respiratory burst activity in blood of $L$. rohita $\mathrm{H}$. Values are the mean $\pm \mathrm{SE}$. Means bearing different superscripts are statically significant $(P<0.05)$

\section{Hematological effect}

Hematological analysis showed significantly higher levels $(P<0.05)$ of RBCs and hemoglobin content in group $T_{1}$ and $T_{2}$ diets as compared to the control diet (Table 5). Moreover, these values were significantly higher $(P<$ $0.05)$ in nano-iron diet $\left(T_{1}\right)$-treated group than in the $T_{2}$ group. However, WBCs content, total serum protein, albumin, globulin and albumin/globulin ratio showed no significant differences among all the treated groups, such as $T_{1}, T_{2}$ and control diet.

\section{Immunological studies}

Respiratory burst activity and serum bactericidal activity were significantly increased $(P<0.05)$ in both iron treatment groups $\left(T_{1}\right.$ and $\left.T_{2}\right)$ as compared to control (Figs. 1 and 2 , respectively) after $30 \mathrm{dpi}$. However, there is a significant higher $(P<0.05)$ respiratory burst and serum bactericidal activities in nano-iron-treated group $\left(T_{1}\right)$ as compared to the $T_{2}$ group. However, there were no significant differences in alternative complement activity among $T_{1}, T_{2}$ and the control (Fig. 3).

Antioxidant enzymatic activities and lipid peroxidation analysis

The potential impact of nano-Fe on antioxidant enzymatic activities and lipid peroxidation (SOD, GSH and MDA)

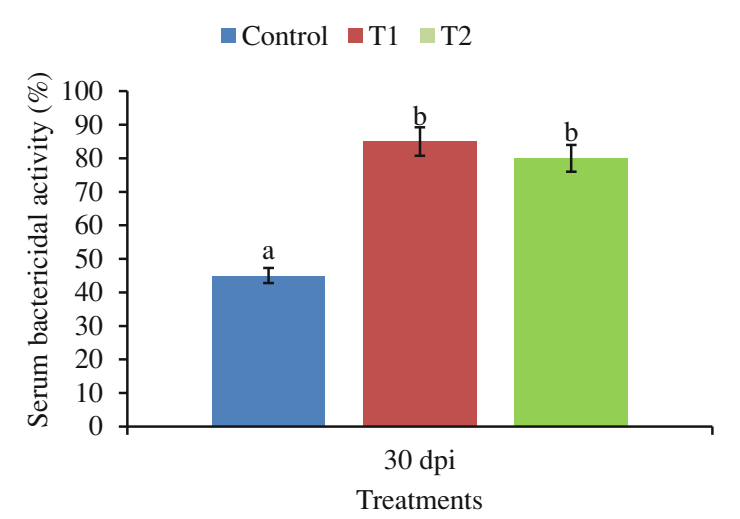

Fig. 2 Effect of dietary iron on serum bactericidal activity of L. rohita $\mathrm{H}$. Values are the mean $\pm \mathrm{SE}$. Means bearing different superscripts are statically significant $(P<0.05)$

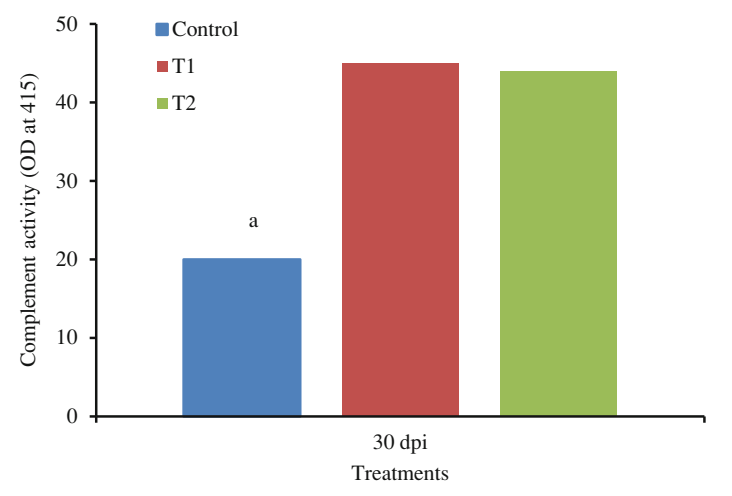

Fig. 3 Effect of dietary iron on serum complement activity of L. rohita $\mathrm{H}$. Values are the mean $\pm \mathrm{SE}$. Means bearing different superscripts are statically significant $(P<0.05)$

was investigated by taking liver tissues of all the treated groups after 30 days of culture. Lipid peroxidation measured by MDA assays (Fig. 4) showed no significant difference in both $T_{1}$ and $T_{2}$ as compared to control. In addition, both GSH (Fig. 5) and SOD (Fig. 6) activities were significantly higher in both $T_{1}$ and $T_{2}$ compared with the control. However, both SOD and GSH showed no significant difference between $T_{1}$ and $T_{2}$.

\section{Discussion}

Dietary iron supplementation is necessary and Roeder and Roeder (1966) demonstrated that the growth of fish was 


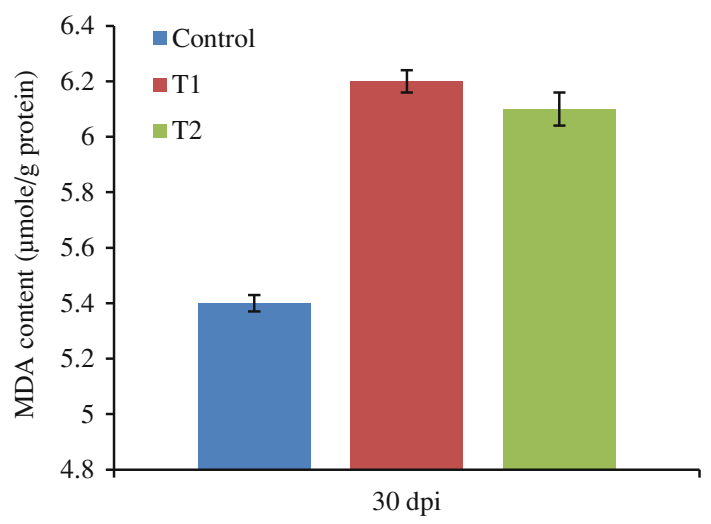

Fig. 4 Lipid peroxidation activities (MDA assays) in liver tissues of L. rohita $\mathrm{H}$. after $30 \mathrm{dpi}$

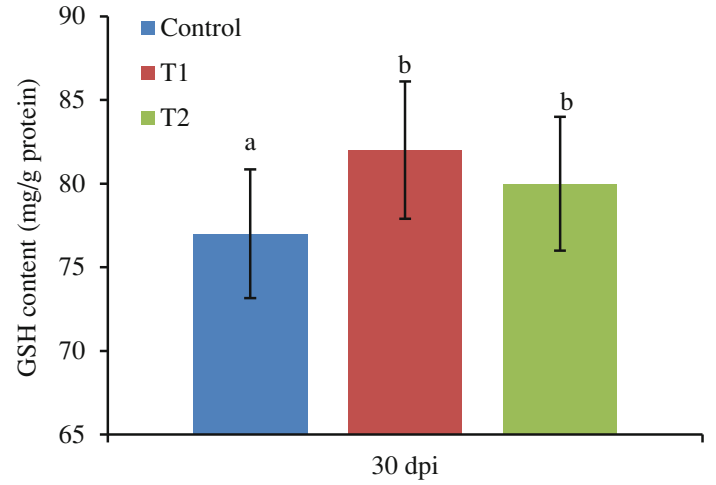

Fig. 5 GSH activities in liver tissues of $L$. rohita $\mathrm{H}$. after $30 \mathrm{dpi}$

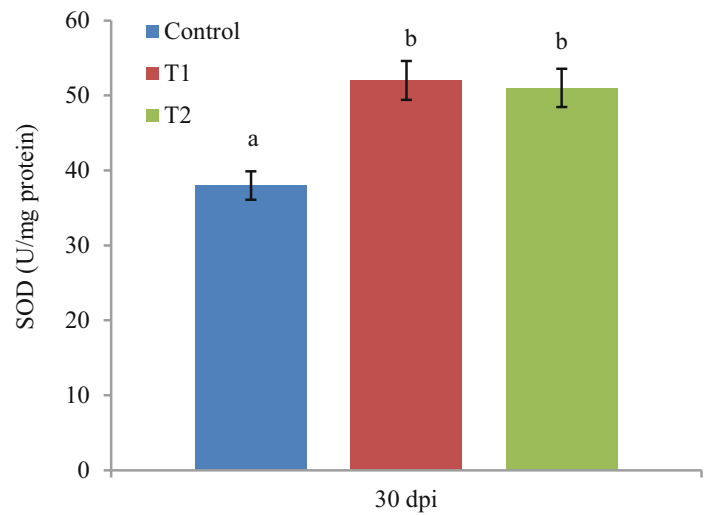

Fig. 6 SOD activities in liver tissues of $L$. rohita $\mathrm{H}$. after 30 dpi

affected by dietary iron level. Little is known about iron metabolism in fishes. To our knowledge, this is the first report investigating the potential nutritional and immunological value of iron nanoparticles in fishes. According to Roeder and Roeder (1966), addition of ferrous sulfate to water in which fishes were raised appeared to have a stimulatory effect on the growth of these fishes, as compared to untreated controls (Roeder and Roeder 1966).
It clearly indicated that iron-supplemented diet could improve the final weight of Indian major carp, Labeo rohita $\mathrm{H}$, whereas fishes showed growth retardation when given a purified diet without iron supplementation (Gatlin and Wilson 1986). Mortality noted in fishes fed an iron-deficient diet was prevented by administration of a diet containing optimum iron level. The nano-dispersed form of iron in feed drastically reduced mortality rate in commercial fish farms of carp and sturgeon (Prochorov et al. 2011). In this experiment, no mortality was recorded in any of the iron-treated group. It was obvious that the iron contents in muscle were markedly changed with the addition of dietary iron and was significantly $(P<0.05)$ higher in $T_{1}$. The results indicated that nano-Fe and ferrous sulfate had different metabolic pathways, although both the inorganic form crossed the intestinal barrier. Thus iron bioavailability depended not only on its absorption by the intestine, but also on its conversion to a biologically active form (Andersen et al. 1997). In support to the present study, the nano form of iron oxide $\left(\mathrm{Fe}_{2} \mathrm{O}_{3}\right)$ is highly bioavailable (96\% similarity with $\mathrm{FeSO}_{4}$ ) in rats without tissue accumulation (Hilty et al. 2010a, b nature). This shows that nano-Fe could have a special metabolism pathway and deposition mechanism in fish.

Serum iron is a traditional iron status parameter and has been used as an indicator for iron requirement in fish (Gatlin and Wilson 1986). Iron found in the serum is considered a function of iron entering and leaving the blood stream (Silva et al. 2004). In our study, serum iron was improved with nano-Fe-treated diet as compared to other iron sources. This suggested that nano-Fe supplementation significantly increased the absorption and bioavailability of iron. Moreover, less absorption in fish fed a basal diet, deficient in iron, suggested that iron supplementation was necessary for Indian major carps. Hematological assays may provide an index of the physiological status of fish. These parameters are more sensitive to iron supplementation and act as indicator of iron requirements (Chu et al. 2007). In this study, a significant increase in RBCs and hemoglobin was found in three nano-Fe-treated diets unlike use of other iron sources and iron-deficient diet. Similarly, fish receiving nano-disperse form of iron through diet had significantly enhanced erythropoiesis and hemoglobin level, and drastically reduced mortality rate, without any sign of polychromatic anemia (Prochorov et al. 2011). Several reports showed that a deficiency of iron may contribute to several immunodeficiency syndromes such as impaired $\mathrm{T}$ cell functioning, atrophy in lymph organs, etc. in both humans and animals (Farthing 1989). In this study, no immune suppression was observed in all the treated groups. A tendency for increased respiratory burst activity, myeloperoxidase activity and bactericidal activity was observed in the nano-Fe diet group. The in vitro effects of 
magnetic iron oxide nanoparticles on dendritic cell activation (Goya et al. 2008) and enhanced production of interleukins, cytokines, through intravenous administrations in rat (Chen et al. 2011) support our findings. Iron deficiency also causes decreased myeloperoxidase activity, bactericidal activity, neutrophil functions and NBT reductions (Dhur et al. 1989; Farthing 1989; Oppenheimer and Hendrickse 1983; Scrimshaw and San Giovanni 1997). However, alternative complement activity was not significantly influenced by dietary nano-Fe administration in Labeo rohita H. Similarly, in Atlantic salmon, specific hemolytic complement activities were not influenced by the administration of dietary iron sources (both organic and inorganic form) up to 20 weeks (Andersen et al. 1998).

Iron has a number of biological functions in animals including fish. It is well known that dietary iron modulates the antioxidant defense system such as glutathione peroxidase (GSH) and superoxide dismutase (SOD) by preventing free radical production and lipid peroxidation (MDA). By monitoring several biomarkers such as SOD, GSH and MDA after dietary administration of nano-Fe, it was found that no oxidative damages were found. In contrast to this, $\mathrm{Li}$ et al. 2009 suggested that waterborne iron nanoparticle causes oxidative damages at the early exposure period in medaka embryo. However, no terminal oxidative damage occurred during the whole exposure period due to the self-recovering capacity of adult fish (Li et al. 2009). However, in the present study, iron supplemented in the basal diet could improve the SOD and GSH activity irrespective of different iron sources (nano-Fe and ferrous sulfate).

In conclusion, this research demonstrated that different iron sources (nano-Fe and ferrous sulfate) supplemented in the basal diet could improve the final weight and antioxidant enzymatic activities, and induce hematological and immunological parameters of Indian major carps, Labeo rohita $\mathrm{H}$. Moreover, nano-Fe appeared to be more effective than ferrous sulfate in increasing muscle iron and hemoglobin content. Its promising role in raising hemoglobin level may be used in future to treat anemic fish. Despite these promising results, future studies are needed for a complete evaluation of its wide application in various species of fish.

Acknowledgments This work was financially supported by the grant of National Fellow Research Project under Indian Council of Agricultural Research (ICAR). The authors are thankful to the Director, Central Institute of Freshwater Aquaculture (CIFA), Head, Fish Nutrition and Physiology Division, CIFA, Odisha, India for valuable suggestions and help for providing the facilities to carry out this work.

Open Access This article is distributed under the terms of the Creative Commons Attribution License which permits any use, distribution, and reproduction in any medium, provided the original author(s) and the source are credited.

\section{References}

Albrecht MA, Evans CW, Raston CL (2006) Green chemistry and the health implications of nanoparticles. Green Chem 8:417-432

Andersen F, Maage A, Julshamn K (1996) An estimation of dietary requirements of Atlantic salmon, Salmo salar L., parr. Aquacult Nutr 2:41-47

Andersen F, Lorentzen M, Waagbo R, Maage A (1997) Bioavailability and interactions with other micronutrients of three dietary iron sources in Atlantic salmon, Salmo salar, smolts. Aquacult Nutr 3:239-346

Andersen F, Lygren B, Maage A, Waagbo R (1998) Interaction between two dietary levels of iron and two forms of ascorbic acid and the effect on growth, antioxidant status and some nonspecific immune parameters in Atlantic salmon (Salmo salar) smolts. Aquacult 161:437-451

Anderson DP, Siwicki AK (1994) Duration of protection against Aeromonas salmonicida in brook trout immunostimulated with glucan or chitosan by injection and immersion. Prog Fish Cult $56: 258-261$

Barton JC, Edwards CQ (2000) Hemochromatosis: Genetics, pathophysiology, diagnosis and treatment. Cambridge University Press, New York, p 616. ISBN: 0-521-593808

Beisel WR (1982) Single nutrient and immunity. Am J Cli Nutr $35: 417-468$

Bhaskaram P (1988) Immunology of iron deficient subjects. In: Chandra RK (ed) Nutrition and immunology. Alan R. Liss, New York, pp 149-168

Boyd CE, Tucker CS (1998) Pond aquaculture water quality management. Kluwer Academic Publishers, USA

Bury NR, Walker PA, Glover CN (2003) Nutritive metal uptake in teleost fish. J Expl Biol 206:11-23

Chen P-J, Chih-Hsiang S, Chi-Yen T, Shih-Wei T, Chiung-Hsiang C (2011) Toxicity assessments of nanoscale zerovalent iron and its oxidation products in medaka (Oryzias latipes) fish. Mar Pollut Bull 63:339-346

Chu JH, Chen SM, Huang CH (2007) Effect of dietary iron concentrations on growth, hematological parameters, and lipid peroxidation of soft-shelled turtles, Pelodiscus sinensis. Aquacult 269:532-537

Coffman MA (2011) The best bioavailable iron supplements. http://www.livestrong.com/article/488167-the-best-bioavailableiron-supplements/

Dhur A, Galan P, Hercberg S (1989) Iron status, immune capacity, and resistance to infections. Comp Biochem Phys A-Comp Phys 94:11

Doumas BT, Watson WA, Biggs HG (1971) Albumin standards and the measurement of serum albumin with bromocresol green. Clin Chem Acta 31:87-96

Drabkin DL (1950) The distribution of the chromoproteins, hemoglobin, myoglobin, and cytochrome $\mathrm{C}$, in the tissues of different species, and the relationship of the total content of each chromoprotein to body mass. J Biol Chem 182:317-333

Farthing MJ (1989) Iron and Immunity. Acta Paediatr Scand Suppl $361: 44-52$

Forbes AL, Arnaud MJ, Chichester CO, Cook JD, Harrison BN, Hurrell RF, Kahn SG, Morris ER, Tanner JT et al (1989) Comparison of in vitro, animal, and clinical determinations of iron bioavailability: International Nutritional Anemia Consultative Group Task Force report on iron bioavailability. Am J Clin Nutr 49:225-238

Gatlin DM, Wilson RP (1986) Characterisation of iron deficiency and the dietary iron requirement of fingerling channel catfish. Aquacult 52:191-198

Gibson RS (1990) Principles of Nutritional Assessment. Oxford University Press, New York 
Goya GF, Marcos-Campos I, Fernandez-Pacheco R, Saez B, Godino J, As L, Lambea J, Tabuenca P, Mayordomo JI, Larrad L, Ibarra MR, Tres A (2008) Dendritic cell uptake of iron-based magnetic nanoparticles. Cell Bio Int 32:1001-1005

Hem ID (1989) Study and Interpretation of the Chemical Characteristics of Natural Water, 3rd edn. US Geological Survey WaterSupply, Paper 2254, United States Government Printing Office, Washington, DC

Hilty FM, Knijneburg JTN, Teleki A, Krumeich F, Hurrell RF, Pratsinis SE, Zimmermann MB (2010a) Incorporation of Mg and $\mathrm{Ca}$ into nanostructured $\mathrm{Fe}_{2} \mathrm{O}_{3}$ improves $\mathrm{Fe}$ solubility in dilute acid and sensory characteristics in foods. J Food Sci. doi: 10.1111/J.1750-3841.2010.01885.X

Hilty FM, Arnold M, Hilbe M, Teleki A, Knijnenburg JT, Ehrensperger F, Hurrell RF, Pratsinis SE, Langhans W, Zimmermann MB (2010b) Iron from nanocompounds containing iron and zinc is highly bioavailable in rats without tissue accumulation. Nat Nanotechnol 5:374-380

Hilty FM, Knijnenburg JTN, Teleki KF, Hurrell RF, Pratsinis SE, Zimmermann MB (2011) Incorporation of $\mathrm{Mg}$ and $\mathrm{Ca}$ into nanostructured $\mathrm{Fe}_{2} \mathrm{O}_{3}$ improves $\mathrm{Fe}$ solubility in dilute acid and sensory characteristics in foods. J Food Sc 76:1-10

Huber DL (2005) Synthesis, properties, and applications of iron nanoparticles. Small 1:482-501

Jhingran VG, Pullin ISV (1985) A hatchery manual for the common, Chinese and Indian major carps. ICLARM Studies and Reviews 11, Asian Development Bank, Manila, Philippines and International Center for Living Aquatic Resources Management, Manila, Philippines, p 191

Kawatsu H (1972) Studies on the anaemia of fish. 5. Dietary iron deficient anaemia in brook trout, Salvelinus fontinalis. Bull Freshw Fish Res Lab (Tokyo) 22:59-67

Lall SP (2002) The Minerals. In: Halver JH, Hardy RW (eds) Fish Nutrition, 3rd edn. Academic Press, CA, pp 260-366

Lee YH, Layman DK, Bell RB, Norton HW (1981) Response of glutathione peroxidase and catalase to excess dietary iron in rats. J Nutr 111:2195-2202

Li H, Zhou Q, Wu Y, Fu J, Wang T, Jiang G (2009) Effects of waterborne nano-iron on medaka (Oryzias latipes): antioxidant enzymatic activity, lipid peroxidation and histopathology. Ecotoxicol Environ Safety 72:684-692

Lovell RT (1998) Nutrition and feeding of fish, 2nd edn. Kluwer Academic Publishers, Boston

Melodie A (2011) What iron supplements best increase ferritin? http://www.livestrong.com/article/510513-what-iron-supplementsbest-increase-ferritin/

Min BR, Nam KC, Cordray JC, Ahn DU (2008) Factors Affecting Oxidative Stability of Pork, Beef, and Chicken Meat, Animal Industry Report: AS 654, ASL R2257. http://lib.dr.iastate.edu/ ans_air/vol654/iss $1 / 6$

NRC (National Research Council) (1993) Effect of iron on the growth rate of fishes
Ohkawa H, Ohishi N, Yagi K (1979) Assay for lipid peroxides in animal tissues by thiobarbituric acid reaction. Anal Biochem 95:351-358

Oppenheimer SJ, Hendrickse RG (1983) The clinical effects of iron deficiency and iron supplementation. Nutr Abstr Rev 53: $585-598$

Prochorov AM, Pavlov GV, Godwin AC, Okpattah KAV (2011) The effect of nano-disperse iron on the biological parameters of fish. In: An abstract in 10th Foresight Conference on Molecular Nanotechnology

Rainger GE, Rowley AF (1993) Antibacterial activity in the serum and mucus of rainbow trout, Oncorhynchus mykiss, following immunization with Aeromonas salmonicida. Fish Shellfish Immunol 3:475-482

Roeder M, Roeder RH (1968) Effect of iron on the growth rate of fishes. J Nutri 90(1):86-90

Rohner F, Ernst FO, Arnold M, Hilbe M, Biebinger R, Ehrensperger F, Pratsinis SE, Langhans W, Hurrell RF, Zimmermann MB (2007) Synthesis, characterization, and bioavailability in rats of ferric phosphate nanoparticles. J Nutr 137:614-619

Sakamoto S, Yone Y (1978) Iron deficiency symptoms of carp. Bull Japanese Soc Sci Fish 44:1157-1160

Salte R, Rørvik KA, Reed E, Nordberg K (1994) Winter ulcers of the skin in Atlantic salmon, Salmo salar L.: pathogenesis and possible aetiology. J Fish Dis 17:661-665

Scrimshaw NS, San Giovanni JP (1997) Synergism of nutrition, infection, and immunity: an overview. Am J Clin Nutr 66:464S$477 \mathrm{~S}$

Sealey WM, Lim C, Klesius PH (1997) Influence of dietary level of iron from iron methionine and iron sulfate on immune response and resistance of channel catfish to Edwardsiella ictaluri. J World Aquacult Soc 28:142-149

Silva LF, Dutra-de-Oliveira JE, Marchini J (2004) Serum iron analysis of adults receiving three different iron compounds. Nutr Res 24:603-611

Sitja-Bobadilla A, Mingarro M, Pujalte MJ, Garay E, AlvarezPellitero P, Perez- Sanchez J (2003) Immunological and pathological status of gilthead sea bream (Sparus aurata L.) under different long-term feeding regimes. Aquacult 220: $707-724$

Stephen D (2007) Nano iron could boost human bioavailability. http://www.nutraingredients.com

Tacon AJ (1992) Nutritional fish pathology. Morphological signs of nutrient deficiency and toxicity in farmed fish. FAO Fish Technical Paper. No. 330, Rome, FAO, p 75

Wang HL, Zhang JS, Yu HQ (2007) Elemental selenium at nano size possesses lower toxicity without compromising the fundamental effect on selenoenzymes: comparison with selenomethionine in mice. Free Radical Bio Med 42:1524-1533 